(7)

\title{
Financial Inclusion and Economic Growth: Empirical Evidence from Selected Developing Economies
}

\author{
${ }^{a}$ Noor ul Ain, ${ }^{b}$ Samina Sabir, ${ }^{c}$ Nabila Asghar \\ ${ }^{a}$ Kashmir institute of Economics, the University of Azad Jammu and Kashmir, Muzaffarabad, Pakistan \\ b Assistant Professor, Kashmir institute of Economics, the University of Azad Jammu and Kashmir, \\ Muzaffarabad, Pakistan \\ c Assistant Professor, Department of Economics and Business Administration, Division of Social \\ Sciences, University of Education Lahore, Pakistan
}

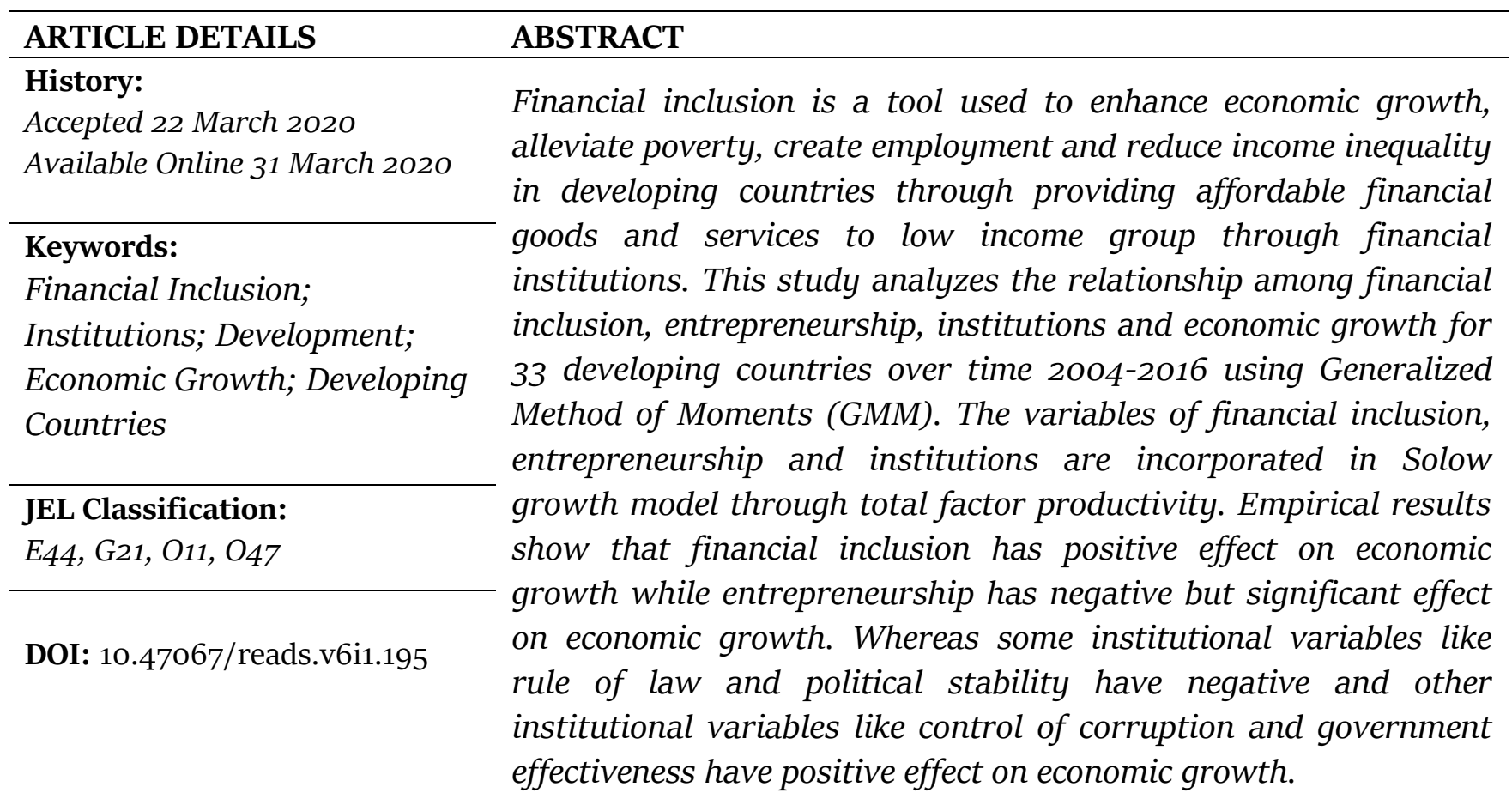

(C) 2020 The authors. Published by SPCRD Global Publishing. This is an open access article under the Creative Commons Attribution-

NonCommercial 4.0

Corresponding author's email address: drnabeelakhan.ecu@gmail.com

\section{Introduction}

In developing countries of Africa and Asia, majority of people are not using the goods and services provided by financial institution or they do not have any bank account even. There are certain factors that lead to financial exclusion such as low income, financial illiteracy, lack of proper documentation, distant financial institution and complex financial goods and services (Oji, 2015). According to Global Findex Database (2014), almost 2 billion young people do not have bank account in 
any bank; they are not using banking services especially in developing countries. There are many other reasons for not having account such as lack of money, geographical reasons, strict conditions of banks etc. Due to financial exclusion poverty increases and economic growth decreases in developing countries. Financial inclusion got importance in the world especially in developing countries since 2000. In 2015, the World Bank group and its other 14 partners had announced the strategy named as Universal Financial Access by 2020 (UFA2020) to enhance the inclusion of finance in the world. The objective of UFA2O2O is to increase the access to the transaction account for storing money, sending payments and receiving deposits to fulfill the financial needs by all the adults of world. Through the Universal Financial Access 2020 initiative, the World Bank and International Finance Corporation (IFC) have targeted 1 billion people to make them able to gain access to transaction account. In 2016, the World Bank has added 16 new partners who made commitment to achieve the target of UFA2020 by the end of year 2020 .

Financial inclusion means timely provision of affordable financial goods and services to the exclusive group such as needy and lower income group. Different economists and organizations define financial inclusion in different ways. But all give the same meanings like access to financial goods and services at reasonable price for all members of society especially poor group by formal financial institutions. Financial inclusion includes micro-saving, micro-credit, micro-insurance, sending and receiving payments etc.

Financial institutions particularly commercial banks play major role in promoting financial inclusion. The primary function of banks is to deposit money and grant loans. They play intermediary role between savers and investors to mobilize savings. Banks are the source of finance for those who have entrepreneurial abilities and skills. According to Archana (2013), micro financial institutions (MFIs) and commercial banks play key part in increasing financial inclusion through channeling funds in the shape of loans to poor people of the economy. As a result new business start, employment increases, income level rises, demand for goods and services increases, productivity increases, and hence poor people also contribute in increasing economic growth.

Now a days the word financial inclusion is getting importance throughout the world. Through inclusive financial system poor people get benefits by using broad range of financial services at low price (Kunt and Klapper 2012). Inclusive financial system in which banks is a major part, creates link between different sectors of the economy and thus provide effective and suitable environment for different government policies to work effectively. When financial system is inclusive then financial institutions would be able to create credit to start economic activities. Policy makers and financial institutions of developing and advanced countries are making and implementing different strategies to promote financial inclusion at individual as well as global level. Due to the effectiveness of inclusive financial sector on growth, governments, banking sector and international financial regulatory bodies have started initiatives to make the financial system inclusive since 2000. For example steps taken by governments include legislative measures, the Community Reinvestment Act (1997) of the United States, The French law against exclusion (1998), Financial Inclusion Task Force (2005) by United Kingdom. At country level Banks of different countries took different steps like German Bankers Associations voluntary code (1996), Mzansi (2004) by the South African Banking Association, facilities of "no-frills" accounts and "General Credit Cards" by Reserve Bank of India (2005), National Financial Inclusion Strategy (NFIS) by few developing countries.

Economic growth has important policy implication for the welfare of the society. Growth is the single important factor affecting the income of the poor. Therefore economic growth is the key to 
understand how to increase the income of the poor to bring them out of poverty. This is the reason that economic growth is eighth goal set by the United Nations Sustainable Development goals(UNSDGs) because it has positive impact on level of employment, level of national income and hence living standards of people.

Financial inclusion ranked the seventh in the sustainable development goals. Financial inclusion got importance throughout the world due to its substantial impacts on growth, entrepreneurship, employment, income inequality and poverty alleviation (Dixit and Ghosh, 2013; Onaolapo, 2015; Fadan, 2014). Financial inclusion has positive impacts on individuals level of income and thereby, economy as whole. Enhancing financial inclusion modernizes the agriculture, promotes innovation, surges entrepreneurship and increases growth (Kelkar, 2010). For low income group, access to credit creates entrepreneurship as well as investment opportunities, output increases and hence growth increases (Islam and Mamun, 2011).

In the late 2000, the importance of financial sector development with respect to growth has been recognized through different studies. King and Levine (1993) examined the relationship between growth and finance. Financial institutions finance those entrepreneurs which introduce innovative and new goods in the market and results in economic growth. In low income and lower middle income countries, it has been seen that people have entrepreneurial abilities but they are deficient in financial facilities or have banking financial facilities at difficult or complex conditions. Some people use informal credit facility that may result in their exploitation (Onaolapo, 2015). By Rajan and Zingales (1996), the key role played by the financial sector is to reallocate the funds of those people have more amount of capital to those people have deficient in funds. Finance may simply enable the pursuit of investment opportunities, and thereby contribute in long run growth. Their work also proved that imperfection in financial market has an effect on investment and growth. Developing countries are eager to achieve inclusive growth which can be possible through financial inclusion. Financial services such as remittances, savings and insurance are considered very necessary for economic development and reduction of poverty because they likely make financial system stable, minimize the differences in income and resource distribution and hence results in inclusive growth (Dhillon and Mittal, 2016). Without inclusive financial system lower income group has insufficient resource/income to get education or to become entrepreneur that creates hurdle in the development of human capital (Beck, Demirguc-Kunt, and Levine, 2007; and World Bank, 2008). Likewise small and medium firms must depend on their own limited income to continue their growth process. Without lending infrastructure the access to finance is limited and the absence of lending infrastructure become obstacle in the way of making financial system inclusive (Asia-Pacific Forum, 2016).

Dixit and Ghosh (2013) studied financial inclusion as a tool for inclusive growth in Indian states. Financial inclusion play major role in growth through generating and mobilizing the resources. Financial inclusions (via providing financial services) mobilize and allocate resources especially to that group of people who have not easy access to them. Alter and Yontcheva (2015) examined financial inclusion and development in the Central African Economic and Monetary Community (CEMAC) region and compared with peers of Sab-Saharan Africa (SSA). All the CEMAC countries have less inclusive and less developed financial sector due to inflation, worse credit information and higher cost ratio.

Institutions are also important for the economic growth of country besides financial inclusion, fiscal policy, entrepreneurship etc. Institutions can be financial, economic, political etc. Institutions play important role in development of countries. Alter and Yontcheva (2015) found that CFA (African Financial Community) countries in Sub Saharan Africa have developed financial sector due to strong 
political institutions. Financial inclusion and institutions both play very important role in economic growth. In Nigeria financial inclusion does not contribute in economic growth because of poor performance of the institutional setup (Adetiloye, 2017). Nystrom (2008) found positive effect of institutional setup on entrepreneurship (self employment). Institutional variable is measured with economic freedom index consist of consists of five variables ( size of the government sector, access to sound money, security of property rights, terms and conditions for international trade and quality of rules/ regulation of credit, labor and business).

Different studies showed that financial inclusion is a key to enhance growth and alleviate poverty. The present study examines the impact of financial inclusion, entrepreneurship and institutions on economic growth. In present study, the financial inclusion, entrepreneurship and institutions are taken together to see their impact on economic growth of developing countries which was hardly done in earlier studies up to our knowledge.

On the basis of availability of data, 33 developing countries are taken over time period 20042016 in this study. System GMM is used to estimate the impact of financial inclusion, entrepreneurship and institutions on economic growth.

This study is structured as follows: Literature reviewed related to financial inclusion, entrepreneurship, institutions and economic growth is presented in section 2. Section 3 is about methodology used in this study. Section 4 discusses the empirical results. Section 6 concludes the overall findings of the study.

\section{Literature Review}

This section 2 provides the review of literature related to financial inclusion, economic growth, entrepreneurship and institutions in previous studies.

\subsection{Financial Inclusion And Economic Growth}

King and Levine (1993) investigated the relation between economic growth and financial depth. Average of three measures of growth was taken over the time and three measures are these (i) real per capita GDP growth (ii) real per capita capital stock growth (iii) total productivity growth. Financial inclusion is taken as financial depth and measured by liquid liabilities. They have used secondary data for 77 countries over the period 1960-1989. The study found positive and significant relationship between the real per capita GDP growth, real per capita capital stock growth, total productivity growth and financial inclusion.

The main function of financial sector is to reallocate the funds of those people which have a large amount of capital to those people or firms which are deficient in funds. Finance may simply create investment opportunities, and thereby contribute in long run growth. Financial development may affect the growth in two ways, it lower the cost of capital or lower the cost of external finance. The firms who are lack of finance if given investment opportunities perform better in economy with efficient financial sector. Financial development simply helps firms to escape from problem of funding internally. The industries depending on finance provided outside the industry are larger in countries having developed financial sector. It is proved that imperfection in financial market affects investment and growth (Rajan and Zingales 1996).

Christopoulos and Tsionas (2004) investigated the relationship between financial depth and economic growth in long-run using panel data of ten developing countries. Using panel unit root tests 
and cointegration tests they found positive relationship between financial depth and growth.

Estrada et al. (2010) estimated the impact of financial development on real per capita GDP growth in developing Asia. A panel data from 1987-2008 of 125 developing Asian countries was taken. It is found that overall financial development has positive effect on real per capita GDP growth. Financial depth affects more positively on growth then the financial structure. It is found that efficiency of investment has positive impact on output growth. There is no difference between finance-growth relationship of developing and industrialized countries. According to theory of finance-growth relationship and given literature the findings of this study are same. Both financial development and financial openness has positive affect on growth and are beneficial for it. For developing Asian countries, the effect of financial openness on growth is comparatively larger after post-crisis period. Prochniak and Wasiak (2017) examined the impact of financial sector development and its stability on economic growth of 28 European Union (EU) and 34 Organization for Economic Cooperation and development (OECD) economies. It is theoretically implied that financial sector development and stability has positive effect on output growth. This study used the data over the time period 1993-2013. Different variables representing financial sector are used and each have different impact on growth. Using the Blundell and Bonds GMM estimation method, it is found that credit creation and its enhancement is an important determinant for output growth. The relationship between domestic credit and GDP growth is negative especially for EU countries in the post crisis period which means that over indebtness does not enhance economic growth. Another financial sector variable used in study is nonperforming loans in total gross loans which is also negatively related with GDP growth. Third variable used is bank capital to asset ratio has positive relationship with GDP growth for OECD countries while has negative relationship for EU countries which is spurious relationship. The next variable market capitalization gives interesting result that both positive and negative type of relationship is found with output growth. When the level of capital market development become excessively high then output growth become low after some stage. This is true for countries which have well stabled capital markets. On the other hand countries having capital markets in the initial stage of development, development of capital markets leads to faster output growth. The model indicates negative relationship of inflation and government consumption expenditures and show positive relation of investment and trade openness on economic growth.

Alter and Yontcheva (2015) examined financial inclusion and development in the Central African Economic and Monetary Community (CEMAC) region as compared with peers of Sab-Saharan Africa (SSA). They also found the determinants of financial development in CEMAC region. They used panel data regressions for the time period 1997-2012, where all the variables are averaged over four years. Macroeconomic variables such as per capita income is positively related, inflation and share of natural resource are negatively related to financial development. Institutions, financial sector, population and technological advances variables impact on financial development. It is interesting in the study that low and high income countries are both far from the financial development stage. They also identify the countries which have achieved the financial development target and also recommend policy measures to CEMAC countries by which they can increase or boost financial inclusion.

Dixit and Ghosh (2013) studied financial inclusion as an instrument for inclusive growth in Indian states. In this paper they realized that the inclusive growth is important and financial inclusion is a tool to achieve it. Using secondary data on variables, it is found that to achieve comprehensive growth there is need of equal distribution of financial inclusion opportunities. There is a need of resources to attain the objective of inclusive growth. Financial inclusion plays important role in economic growth through generating and mobilizing the resources. 
Through formal financial system the inclusive finance for all units of economy affects economic activities. In urban areas, people engaged in productive economic activities, low income earners and small businessmen get special benefits from financial inclusion. Onaolapo (2015) studied the effects of financial inclusion on growth of Nigeria for data of thirty years (1982-2012). Different models like Sustainable Financial Model, Social Development model, Financial Ecosystem model and financial inclusion lifecycle model are given to point out the problems of financial exclusion and give suggestions to achieve full financial inclusion for the reduction of unbanked people. Using OLS techniques the study finds that there is positive relation between growth and financial inclusion. Also financial inclusion plays role in poverty reduction. Financial inclusion has also link with financial intermediation. In most of the low and lower middle income countries, it is seen that people have entrepreneurial abilities but they do not have financial resources to generate their own business. Some people use informal credit facility that may result in their exploitation. This study also suggests enhancing financial intermediation among the rural poor to promote economic growth.

Financial development, such as easy access to loans and more credit facilities create more investment and productive opportunities that leads to growth. Financial development gives advantage to investors that lead to upward shift in production function. An established and well developed domestic financial sector is required to generate higher amount of remittances from abroad. As a result both higher amount of remittances and financial development generate higher steady state level of output and capital stock. Unbreen and Nawaz (2014) found that remittances and financial development increases the steady state rate of output growth and capital stock in the long run. They extended the Ramsay Cass Koopmans model of growth by including remittances and financial development in the financial sector for open economy. They found that at the initial stage, financial development leads to increase in consumption and net output that might appear in the form of trade deficit but in long run it appears in the form of trade surplus. They concluded that a well-developed financial sector with higher amount of remittances directly effects economic growth.

Fadan (2014) investigated the financial inclusion as tool for eradicating poverty and equitable distribution of income for developing countries especially for Nigeria. In Nigeria, Central bank has adopted the National Financial Inclusion Strategy to increase the financial inclusion. Financial inclusion ensures simple and complex financial services to their customers. Simple services include credit and saving facility while complex services include pension and insurance facilities. Study revealed that in 2012, 46.3\% population are financially excluded mostly are of age below 45 having no formal education living in rural areas. $80 \%$ of financially excluded people live in rural areas of Nigeria. Three key barriers in way of financial inclusion are physical access, eligibility and financial literacy. He concluded that financial inclusion is a tool for eradicating poverty and equal distribution of money and most of the developing countries of the world are giving attention to financial inclusion to redistribute income and to alleviate poverty.

In Africa, not more than $25 \%$ of young people have access to formal financial services. Individuals and small industries have less reach to financial services as compared to other developing countries. No money, high cost, distance and documentation are major obstacles in way of financial exclusion. Despite advances in financial sector services in last two decades, individual and firms are excluded from financial sector services. Demirguc-Kunt and Klapper (2012) examined the overall condition of financial inclusion in Africa as compared with other developing countries of the world. Most of the adults in Africa use traditional way of saving and borrowing until now. Likewise SMEs face problems to get finance through financial sector. Half of the firms in Africa have not access to finance 
by financial institution as big barrier in their way of growth. Although African firms having bank account are comparatively more than firms of other developing countries but these firms depend on internal funding. More than $84 \%$ of SMEs finance in Africa is internally financial. Innovations like mobile money can engage more people to transfer money and pay bills at low cost with more access.

Archana (2013) highlighted institutions and their role in financial inclusion. According to Archana, Regional Rural banks (RRBs), Self Help Groups (SHGs), Micro Finance Institutions (MFIs) and commercial banks are playing key role in financial inclusion for last few decades in India. Financial inclusion is necessary part of inclusive growth and helps in alleviating poverty hence public and private sector is working together to promote financial inclusion in India. Regional rural banks are small man's banks having more ability to mobilization of deposits and credit creation to small borrowers in rural areas as compared to commercial banks. Similarly SHGs and MFIs are also playing their best role in financial inclusion through micro financing in rural areas for poor. SHGs are non-institutional channel of micro financing and are playing most effective role in financial inclusion in which 90\% of members are women. Through SHGs-bank linkage program, commercial bank directly lend to SHGs where delivery and recovery of credit is timely and assured. MFIs are source of micro financing for poor in specific areas of India but playing significant part in inclusion of finance. In India institutions with the help of commercial banks are playing their role to alleviate poverty and to empower poor people of rural areas.

Hariharan and Marktanner (2012) estimated effect of financial inclusion on growth. Financial inclusion is a key of growth and development as it has ability to make capital. Output depends on capital and total factor productivity in production function and financial inclusion affect output growth either by capital accumulation or total factor productivity. Moreover due to increase in financial inclusion, the total factor productivity increases by creating link between saving and investment. Different countries have different reasons for lack of financial inclusion. World is divided into financial inclusion surplus and deficit regions. It is empirically resulted that $10 \%$ rise in financial inclusion rises $1.34 \%$ of per capita income.

Babajide et al. (2015) investigated the effect of financial inclusion on growth. Financial inclusion is a process to qualify and to make efficient the financial intermediary goods and services. Financial inclusion is the part of financial development and it creates and collects savings and then change into productive investments. Half of the total wealth of Nigeria is shared by only $10 \%$ of the population. Nigeria is the third largest economy of the Africa. Despite the fact that Nigeria's GDP growth on average is $7 \%, 67.1 \%$ of the Nigerian population is living below the poverty level. The government of Nigeria is giving importance to financial inclusion and targeted to achieve full inclusion by 2020. As aggregate production function is concerned, the financial effect is considered by changing saving and investment into output through two channels 1. By capital accumulation. 2. By technological change. Using secondary data on ordinary least square regression equation model it is resulted that capital per worker is the main factor of financial inclusion and financial inclusion itself is the main factor as well as bank deposit rate and total number of resource rents are also factors for determining the output growth in the Nigerian economy.

After the emergence of shari'a complaint financial services and insurance Kim et al. (2018) examined the relation between growth and financial inclusion for 55 member Islamic countries of Organization of Islamic Countries (OIC). Financial inclusion is gaining importance in recent decades among scholars, politicians and financial stakeholders. Shari'a complaint financial products are more attractive towards investment as compared to western financial products so financial inclusion in 
Islamic countries play important role for growth of economy. They took per capita GDP as proxy of growth and five variables to measure financial inclusion. Results of dynamic panel estimation found that financial inclusion has positive impact on growth and has mutual causalities with each other.

Adetiloye et al. (2017) examined the effect of financial inclusion on growth as well as on poverty. He used variables like loan to deposit ratio, liquidity ratio, broad money to GDP (ratio), credit to private sector, commercial bank branches and demand deposits for rural areas to measure financial inclusion. Using data of Nigerian economy over the time period 1986-2015, it is concluded that financial inclusion does not support growth in Nigeria while financial inclusion helps in alleviating poverty. It is recommended in the study that resources should be allocated and utilized efficiently by making strong the regulatory framework.

\subsection{Institutions, Entrepreneurship And Economic Growth}

Commander and Nikoloski (2010) analyzed the impact of institutions on economic performance of countries and firms. Various institutional measures are taken and their impact on economic performance has been analyzed separately. In this paper institutional measures taken are political system (democracy or not), business and investment environment. Growth in per capita income and real GDP growth are used as proxy for economic performance. Data of 159 economies is taken over the time period from 1960-2009. GMM estimation is used and found positive but insignificant relationship between growth measures and political system. To find the relationship between growth performance and institutions the data over the period 2003-2007 was used and found little statistically significant relationship between them.

Autio and $\mathrm{Fu}$ (2015) investigated the effect of quality of political and economic institutions on entrepreneurship. He used the data of 18 countries from Asia Pacific region over the time period 20012010. Dependent variable is population prevalence of entrepreneurship. It is found that good quality of economic and political institutions has direct and positive impact on formal entrepreneurship. If institutions lack quality then more entrepreneurs will choose informal entrepreneurship. It is also found that good quality of economic and political institutions are necessary for entering entrepreneurs to formal entrepreneurship.

Chen and Jin (2017) examined the use of credit an important indicator of financial inclusion in China. This study used the primary data of China Household Financial Studies (CHFS 2011) dataset. Data was gathered from 28000 members of 8438 households using stratified random sampling. Dependent variable used in the study is use of credit while socio-demographic variables like gender, education, employment etc. are used as independent variables. Results show that household use of credit taken from financial institution (formal credit) is low and use of credit taken from other sources (informal credit) is high while use of formal credit is positively related with employment, education, income, asset and urban residence. The low level of formal credit was due to less credit creation by banks and lack of financial knowledge. The findings of study suggest that to increase financial inclusion policies should be designed in such a way that increase the access of household to formal credit and increase financial knowledge.

As SMEs and entrepreneurship is important determinant of economic growth. Carvo et al. (2012) showed that SMEs has negative or neutral impact on economic growth of developing countries while for developed countries SMEs and economic growth has positive relationship. This study used the averaged over 3 year data for 25 Brazilian states for the period 1985-2004. The results show that relative size of SMEs has negative impact on economic growth while human capital of SMEs has 
positive impact on economic growth. The negative results between two variables in Brazilian states does not mean that small firms or entrepreneurs should be discouraged as author give reason for negative relationship to institutional failure that encourages rent seeking activities. Hence author suggests promoting institutional and educational improvement as public policy for enhancing economic growth of Brazil.

Martin et al. (2010) investigated the effect of entrepreneurship on economic growth. Schumpeter was one of the earliest economists who included the entrepreneurship variable in growth models and analyzed its effect on economic growth. In Schumpeter views innovation was the instrument to enhance economic growth. Entrepreneurship has also role in promoting economic growth while profit social environment also has influence on it. Martin et al. followed the same concept using GEM (Global Entrepreneurship Monitor) data over the period 2000-2006 for 25 countries. This study used entrepreneurship index calculated by GEM as variable of entrepreneurship and concluded that entrepreneurship has positive but indirect impact on economic growth through private investment. With more entrepreneurship the private investment enhances which leads to more growth.

Nissan et al. (2011) estimated the relationship among organizations, institutions and economic growth. Organizations and institutions have direct as well as indirect role to enhance economic growth. Organizations and institutions play direct role through human capital and play indirect role through entrepreneurship and both has positive impact on economic growth. Growth equation is used to test the hypothesis that whether human capital and entrepreneurship has positive impact on economic growth. OLS estimation technique is used to estimate the data of eleven countries for the time period 200o2005. Organizations and institutions make economic agents able to use new technologies through providing education to them. Institutions especially monetary provide funds to economic agents and make them entrepreneurs. Empirical analysis showed that organizations and institutions play role in economic growth process.

In summary, investment, inflation, Government expenditure, openness rate and population growth are major determinants of economic growth. All these factors are to be used in their right direction for enhancing economic growth under the supervision of good institutions. Through financial inclusion and entrepreneurship lower segment of economy can participate in economic growth where the above factors are also working side by side. Until now, the impact of financial inclusion, entrepreneurship and institutions is analyzed separately. Most of the studies showed theoretical relationship of financial inclusion and economic growth for only one developing country or developing countries of one region. Moreover, impact of financial inclusion, entrepreneurship taking institutions together on economic growth is analyzed much rarely. This study is trying to fill this gap by establishing empirical relationship among them.

\section{Empirical Framework}

The panel data model for current study is written as follows

$$
Y_{i t}=\alpha_{0}+\beta X_{i t}+\delta T_{i t}+\mu_{i t}
$$

Where $\mathrm{i}=$ number of countries and $\mathrm{t}=$ time period (2004-2016). Here " $Y_{i t}$ " represents dependent variable which is economic growth measured with per capita GDP, " $X_{i t}$ " is used to represent vector of control variables that consist of inflation, gross fixed capital formation, trade openness, " $T_{i t}$ " represents our targeted variables such as financial inclusion, institutions and entrepreneurship, $\mu_{i t}$ is error term and $\alpha, \beta$ and $\delta$ are unknown parameters to be estimated. We have used different proxies of 
financial inclusion and institutions rather than index because proxies are considered comparatively reliable than index.

The dynamic panel data model of the study is written as

$$
Y_{i t}=\alpha_{0}+\alpha_{1} Y_{i, t-1}+\theta F I_{i t}+\Phi E_{i t}+\eta I_{i t}+\beta X_{i t}+\mu_{i t}+v_{i}
$$

Where $\mathrm{i}=1, \ldots, \mathrm{N}$ and $\mathrm{t}=1, \ldots, \mathrm{T}$, " $v_{i}$ " is country specific effect and " $\mu_{i t}$ " is error term with zero mean and constant variance and zero covariance between explanatory variables and error term. We assume that $\mathrm{E}\left(\mu_{i t}\right)=\mathrm{o}$ and $\mathrm{E}\left(\mu_{i t} \mu_{j s}\right)=\sigma_{\mu}^{2}$.

If lagged dependent variable appears as explanatory variable then strict exogeneity of the regressors no longer holds. For example growth and some other variables have reverse causation that creates endogeneity problem. In case of economic growth, the institutions can work better and the level of entrepreneurship and financial inclusion rises and vice versa. Secondly some variables are of nature that affects other variables of different countries at the same time like international crises affect growth, financial inclusion and entrepreneurship of different countries at the same time. In such situation the least square dummy variable (LSDV) method cannot be used due to inconsistent estimates obtain from it.

Because of the correlation between lagged dependent variable and error term autocorrelation occurs. The instruments are used to eliminate the problem of autocorrelation. Then we have instrumental variable (IV) technique proposed by Anderson and Hsiao (1982). The equation 2 can be modified as

$$
\begin{aligned}
y_{i t}-y_{i, t-1}= & \alpha_{1}\left(y_{i, t-1}-y_{i, t-2}\right)+\theta\left(F I_{i t}-F I_{i, t-1}\right)+\Phi\left(E_{i t}-E_{i, t-1}\right)+\eta\left(I_{i t}-I_{i, t-1}\right)+\beta\left(X_{i t}\right. \\
& \left.-X_{i, t-1}\right)+\left(\mu_{i t}-\mu_{i, t-1}\right)
\end{aligned}
$$

Where $\left(y_{i, t-2}\right)$ is uncorrelated with $\mu_{i t}-\mu_{i, t-1}$ so it can be used as instrument to estimate known known parameters. Arrellano and Bond (1991) noted that $\left(y_{i, t-2}\right)$ is not the only instrument for $\left(y_{i, t-1}-y_{i, t-2}\right)$ but all $\left(y_{i, t-2-j}\right)$ where $\mathrm{j}=0,1, \ldots .$. are all legitimate instruments for $\left(y_{i, t-1}-y_{i, t-2}\right)$. Hence Arrellano and Bond (1991) proposed first difference GMM technique to estimate panel data model. This technique also uses instruments to remove problem of endogeneity.

Instruments of lagged and explanatory variables are taken in this technique. To check the validity of instruments of system GMM, the Sargan test is used. The higher p-value shows that instruments are valid and accepts null hypothesis.

\subsection{Description Of Variables}

This study takes Economic growth as dependent variable. It is defined as increase in real market value of goods and services of an economy over time. Per capita Gross Domestic product (GDP) is used to measure economic growth (Estrada and Park, 2010; Hariharan and Marktanner, 2012; Babajida, 2015).

Financial inclusion means providing financial goods and services to needy and poor people on time at a low cost. There is no consensus on the measurement of financial inclusion and different proxies are used in different studies. Babajide (2015) used commercial bank deposit (deposit account holders in commercial banks) as proxy of financial inclusion. Hariharan and Marktanner (2012) used 
account at formal financial institution as proxy of financial inclusion whereas Dixit and Ghosh (2013) used index composed of banking penetration, availability of banking services and usage of banking system as proxy of financial inclusion. Onaolapo (2015) used FD1 (ratio of broad money to GDP) and FD2 (ratio of credit to private sector to GDP) as proxy of financial inclusion. In this study we use Commercial bank branches/100,00o adults and Automated Teller machine/100,00o adults as proxy of financial inclusion.

Entrepreneurship means the ability and skills to create, establish and maintain a business that involves risks to earn profit. Data of entrepreneurship is available in form of index in Global Entrepreneurship Monitor (GEM) dataset. Total Entrepreneurship Activity (TEA) index by GEM as measure of entrepreneurship is used in most of the studies by different scholars (Martin et al, 2011; Bjornskov and Foss, 2007; Sobel et al, 2007). Nystrom (2008) used self-employment by COMPENDIA dataset as measure of entrepreneurship. Autio and Fu (2015) combine GEM and World Bank Enterprise snapshot datasets to make proxy to measure entrepreneurship first ever. In this study, new business registered variable is taken as proxy of entrepreneurship.

Institutions are economic and political. Institutional setups that make and regulate the rules for business in an economy are economic institutions. Economic institutions are measured by Business Freedom Index. Institutional setups that make and regulate rule of law, protection of property, access to opportunity are political institutions and are measured by Political Right Index (Autio and Fu, 2015). Some studies used democracy (polity 2 and polity IV) as measure of institutions (Hariharan and Marktanner, 2012; Commander and Nikoloski, 2010). Alter and Yoncheva (2015) used index of government effectiveness, rule of law and political stability using data from Worldwide Governance Indicator. Nystrom (2008) used institutional quality measured by economic freedom index made of five components size of government, legal structure and security of property rights, access to sound money, freedom to trade internationally and regulation of credit, labor and business. In this study we use control of corruption, government effectiveness, political stability and rule of law separately to represent political institution.

Inflation is sustained rise in prices of goods and services over time. Consumer price index is used to measure inflation (Christopoulos and Tsionas, 2004; Giri and Sehrawat, 2017). Caporale et al. (2009) used average consumer prices to measure inflation. Consumer price index is used to measure inflation in this study.

Trade openness is measured as sum of exports and imports divided by GDP (Prochniak and Wasiak, 2017; Giri and Sehrawat, 2017). Caporale et al. (2009) used international trade policy variable as proxy of trade openness in their study which is trade to GDP ratio. In this study trade to GDP ratio is used to measure trade openness.

Gross fixed capital formation is used as investment which is gross domestic fixed investment including land, machinery, purchase of equipment, plant, infrastructure etc. It is taken as percentage of GDP. Gross domestic fixed investment as percentage of GDP is used to measure investment in this study.

Panel data for some selected lower income group and lower middle income group countries is used in this study. Data for all variables is taken from World Development indicators except institutions. Data of institutions is taken from the world Governance indicators. Data for 33 developing countries such as Afghanistan, Bangladesh, Bhutan, Bolivia, Burkina Faso, Congo, Dem. Rep., EI 
Salvador, Georgia, Ghana, India, Indonesia, Kenya, Kosovo, Kyrgyz republic, Lao pdr, Lesotho, Moldova, Mangolia, Morocco, Myanmar, Nepal, Nigeria, Pakistan, Phillpines, Rawanda, Senegal, Srilanka, Timorleste, Togo, Tunisia, Ukraine, Vanuate and Zambia are taken over time period 2004-2016 is taken in this study.

\subsection{Results and Discussions}

To check whether financial inclusion effects economic growth or not, different proxies of financial inclusion and institutional variable are used. New business registered (in number) is used to represent entrepreneurship. The values of institutional variables range between -2.5 to 2.5 . The value 2.5 shows worst institutions while 2.5 shows best institutions. In the study, data of 33 lower income and lower middle income countries is taken to check the effect of financial inclusion,

We examined the impact of financial inclusion, entrepreneurship and institutions on economic growth. Two proxies are used for indicating financial inclusion which are commercial banks branches per 100,000 adults and ATMs per 100,000 adults. To represent entrepreneurship natural log of new business registered (in number) is taken. For institutions control of corruption, political stability, government effectiveness and rule of law are used separately to see their effect on economic growth. Natural log of per capita GDP is taken to represent economic growth. We estimate results in two steps. In step one, four models are estimated in which financial inclusion is measured with Commercial banks branches/10000o adults with four proxies of institutional variables. In second step, another proxy of financial inclusion is used which is ATMs/1000oo adults with four institutional variables and estimate the impact of financial inclusion on economic growth.

\subsection{Emperical Impact Of Commercial Banks Branches/100,00o Adults (Cbbs/100000), Institutions And Entrepreneurship On Economic Growth}

In step one, financial inclusion is measured with commercial bank branches per 100,000 adults. For institutions proxies such as political stability, control of corruption, government effectiveness and rule of law are used. Entrepreneurship is measured with natural log of new business registered (in number). The estimated results are displayed in table 1 to table 4 .

Table 1. Rule of law, financial inclusion and economic growth

\begin{tabular}{|lcc|}
\hline VARIABLES & \multicolumn{2}{c|}{ SYSTEM GMM } \\
\hline Per capita GDP(-1) & One-step & Two-step \\
\hline & $\left(0.935^{* * *}\right.$ & $0.93^{* * *}$ \\
\hline CBsB/100,ooo adults & $0.005^{* * *}$ & $(0.000)$ \\
\hline & $(0.000)$ & $0.005^{* * *}$ \\
\hline Entrepreneurship & $-0.009^{*}$ & $(0.000)$ \\
\hline & $(0.09)$ & $-0.006^{* *}$ \\
\hline Rule of law & $-0.014^{*}$ & $(0.02)$ \\
\hline & $(0.10)$ & -0.009 \\
\hline Trade openness & $0.0002^{* *}$ & $(0.17)$ \\
\hline & $(0.020)$ & $0.0003^{* * *}$ \\
\hline Inflation & $-0.0003^{* * *}$ & $(0.000)$ \\
\hline & $(0.009)$ & $-0.0004^{* * *}$ \\
\hline Gross Fixed Capital Formation & 0.0002 & $(0.000)$ \\
\hline
\end{tabular}




\begin{tabular}{|llc|}
\hline & $(0.68)$ & $(0.009)$ \\
\hline Constant & $0.5387^{* * *}$ & $0.516^{* * *}$ \\
\hline Chi square & $(0.000)$ & $(0.000)$ \\
\hline Sargan(p-value) & 7478.88 & 90973.75 \\
\hline AR2 (p-value) & & 1.00 \\
\hline Observations & 0.05 & 0.35 \\
\hline No of countries & 396 & 396 \\
\hline
\end{tabular}

$*, * *$ and ${ }^{* *}$ represents significance level at $10 \%, 5 \%$ and $1 \%$.

The results show that financial inclusion (CBBs/1000oo adults) is positively related to economic growth. The result is consistent with the findings of previous studies (Onaolapo., 2015; Williams et al., 2017; Adetiloye et al., 2017). The reason may be that increase in financial inclusion or increase in number of commercial banks branches means that more people get connected to banking services which increase their ability to save and invest in turn productive activities of economy increases hence output increases. Due to financial inclusion, the poor and needy people get benefits from banks in the form of savings or credit. This increases the productive power of poor and talented entrepreneurs which generates employment in lower sector of economy. Ultimately the production of goods and services increases. Hence output increases that lead to rise in economic growth.

Table 2. Political stability, financial inclusion and economic growth

\begin{tabular}{|c|c|c|}
\hline \multirow[t]{2}{*}{ VARIABLES } & \multicolumn{2}{|c|}{ SYSTEM GMM } \\
\hline & One-step & two-step \\
\hline \multirow[t]{2}{*}{ Per capita GDP(-1) } & $0.942^{* * *}$ & $0.940^{* * *}$ \\
\hline & $(0.000)$ & $(0.000)$ \\
\hline \multirow[t]{2}{*}{ CBsB/100,00o adults } & $0.005^{* * *}$ & $0.005^{* * *}$ \\
\hline & $(0.000)$ & $(0.000)$ \\
\hline \multirow[t]{2}{*}{ Entrepreneurship } & $-0.009^{*}$ & $-0.008^{* *}$ \\
\hline & $(0.09)$ & $(0.02)$ \\
\hline \multirow[t]{2}{*}{ Political stability } & $-0.006^{* *}$ & $-0.007^{* * *}$ \\
\hline & $(0.024)$ & (0.011) \\
\hline \multirow[t]{2}{*}{ Trade openness } & 0.0002 & $0.0002^{* * *}$ \\
\hline & $(0.26)$ & $(0.001)$ \\
\hline \multirow[t]{2}{*}{ Inflation } & $-0.0004^{* *}$ & $-0.0004^{* * *}$ \\
\hline & $(0.003)$ & $(0.000)$ \\
\hline \multirow[t]{2}{*}{ Gross Fixed Capital Formation } & 0.0003 & $0.0003^{* * *}$ \\
\hline & $(0.57)$ & $(0.005)$ \\
\hline \multirow[t]{2}{*}{ Constant } & $0.4940^{* * *}$ & $0.507^{* * *}$ \\
\hline & $(0.000)$ & $(0.000)$ \\
\hline Chi square & 7469.43 & 61302.73 \\
\hline Sargan(p-value) & & 1.00 \\
\hline
\end{tabular}




\begin{tabular}{|lll|}
\hline AR2 (p-value) & 0.06 & 0.37 \\
\hline Observations & 396 & 396 \\
\hline No of countries & 33 & 33 \\
\hline
\end{tabular}

${ }^{*},{ }^{* *}$ and ${ }^{* *}$ represents significance level at $10 \%, 5 \%$ and $1 \%$.

Rule of law/ Political stability and entrepreneurship are negatively related to economic growth. Van Stel et al. (2005) found the same result for developing countries and Cravo et al. (2012) found the same result for Brazil. Cravo et al. (2012) give the institutional failure as reason of this negative relationship between entrepreneurship and growth. The poor performance by institutions of developing countries does not promote the productive entrepreneurship and full use of human skills. Martin et al (2010) showed in his study that entrepreneurial activity has positive but indirect (through investment) effect on economic growth. Better institutions of the country provide regulatory framework and supervision which allocates resources efficiently. In case of better institutions, not only the process of financial inclusion increases efficiently to achieve target level but also give security to small businessman and entrepreneurs.

Table 3. Control of corruption, financial inclusion and economic growth

\begin{tabular}{|c|c|c|}
\hline \multirow[t]{2}{*}{ VARIABLES } & \multicolumn{2}{|c|}{ SYSTEM GMM } \\
\hline & One-step & two-step \\
\hline \multirow[t]{2}{*}{ Per capita GDP $(-1)$} & $0.935^{* * *}$ & $0.932^{* * *}$ \\
\hline & $(0.000)$ & $(0.000)$ \\
\hline \multirow[t]{2}{*}{$\mathrm{CBsB} / 100,000$ adults } & $0.005^{* * *}$ & $0.004^{* * *}$ \\
\hline & $(0.000)$ & $(0.000)$ \\
\hline \multirow[t]{2}{*}{ Entrepreneurship } & $-0.009^{*}$ & $-0.006^{*}$ \\
\hline & (o.09) & $(0.06)$ \\
\hline \multirow[t]{2}{*}{ Control of corruption } & 0.004 & $0.009 *$ \\
\hline & $(0.82)$ & $(0.10)$ \\
\hline \multirow[t]{2}{*}{ Trade openness } & $0.0002^{* * *}$ & $0.0002^{* * *}$ \\
\hline & $(0.000)$ & $(0.000)$ \\
\hline \multirow[t]{2}{*}{ Inflation } & $-0.0004^{* * *}$ & $-0.0004^{* * *}$ \\
\hline & $(0.004)$ & $(0.000)$ \\
\hline \multirow[t]{2}{*}{ Gross Fixed Capital Formation } & 0.0002 & $0.0003^{* * *}$ \\
\hline & $(0.66)$ & $(0.004)$ \\
\hline \multirow[t]{2}{*}{ Constant } & $0.55^{* * *}$ & $0.55^{* * *}$ \\
\hline & (0.000) & $(0.000)$ \\
\hline Chi square & 7522.46 & 195086.11 \\
\hline Sargan(p-value) & & 1.00 \\
\hline AR2 (p-value) & 0.04 & 0.35 \\
\hline Observations & 396 & 396 \\
\hline No of countries & 33 & 33 \\
\hline
\end{tabular}

$*, * *$ and ${ }^{* *}$ represents significance level at $10 \%, 5 \%$ and $1 \%$.

Institutional variables (control of corruption and government effectiveness) have positive and 
significant relationship with economic growth. This shows that public and civil services when make policies and implement on those policies independently (without interference of government) then the economic growth of economy rises. In addition, the less corruption or in absence of bribery each individual of economy (owner or labor) works efficiently to gain more in return. Because one knows that one earns what he does. Consequently this leads to growth of economy. Alter and Yontcheva (2015) found significant relationship between financial inclusion and rule of law for Sub Saharan African (SSA) countries. In Sub Saharan Africa (SSA), African financial Community (CFA franc zone) countries have developed financial sector due to better government effectiveness and property rights.

Table 4. Government effectiveness, financial inclusion and economic growth

\begin{tabular}{|c|c|c|}
\hline \multirow[t]{2}{*}{ VARIABLES } & \multicolumn{2}{|c|}{ SYSTEM GMM } \\
\hline & One-step & two-step \\
\hline \multirow[t]{2}{*}{ Per capita GDP(-1) } & $0.935^{* * *}$ & $0.932^{* * *}$ \\
\hline & $(0.000)$ & $(0.000)$ \\
\hline \multirow[t]{2}{*}{$\mathrm{CBsB} / 100,000$ adults } & $0.005^{* * *}$ & $0.004^{* * *}$ \\
\hline & $(0.000)$ & $(0.000)$ \\
\hline \multirow[t]{2}{*}{ Entrepreneurship } & $-0.009^{*}$ & $-0.006^{*}$ \\
\hline & (o.09) & $(0.06)$ \\
\hline \multirow[t]{2}{*}{ Control of corruption } & 0.004 & $0.009^{*}$ \\
\hline & $(0.82)$ & $(0.10)$ \\
\hline \multirow[t]{2}{*}{ Trade openness } & $0.0002^{* * *}$ & $0.0002^{* * *}$ \\
\hline & $(0.000)$ & $(0.000)$ \\
\hline \multirow[t]{2}{*}{ Inflation } & $-0.0004^{* * *}$ & $-0.0004^{* * *}$ \\
\hline & $(0.004)$ & (0.000) \\
\hline \multirow[t]{2}{*}{ Gross Fixed Capital Formation } & 0.0002 & $0.0003^{* * *}$ \\
\hline & $(0.66)$ & $(0.004)$ \\
\hline \multirow[t]{2}{*}{ Constant } & $0.55^{* * *}$ & $0.55^{* * *}$ \\
\hline & $(0.000)$ & $(0.000)$ \\
\hline Chi square & 7522.46 & 195086.11 \\
\hline Sargan(p-value) & & 1.00 \\
\hline AR2 (p-value) & 0.04 & 0.35 \\
\hline Observations & 396 & 396 \\
\hline No of countries & 33 & 33 \\
\hline
\end{tabular}

$*, * *$ and ${ }^{* *}$ represents significance level at $10 \%, 5 \%$ and $1 \%$.

Results show that inflation is negatively related to economic growth. The literature showed that increasing prices can affect negatively the economic activities. Increase in prices of goods decreases the purchasing power and their ability to save. In result the demand for goods and investment decreases that leads to decrease in production of goods and services. As a result the employment level also decreases which leads to fall in economic growth.

Trade openness enhances the economic growth and trade openness is positively related to economic growth. Trade volume positively and significantly effect on economic growth (Yanikkaya., 
2002; Faiza., 2014). More imports and exports of goods and services increase the economic growth.

Table 5: Govt. effectiveness, ATMs and economic growth

\begin{tabular}{|c|c|c|}
\hline \multirow[t]{2}{*}{ VARIABLES } & \multicolumn{2}{|c|}{ SYSTEM GMM } \\
\hline & One-step & two-step \\
\hline \multirow[t]{2}{*}{ Per capita GDP(-1) } & $0.956 * * *$ & $0.955^{* * *}$ \\
\hline & $(0.000)$ & $(0.000)$ \\
\hline \multirow[t]{2}{*}{ ATMs/100,0oo adults } & 0.0002 & $0.0002^{* * *}$ \\
\hline & $(0.57)$ & (0.001) \\
\hline \multirow[t]{2}{*}{ Entrepreneurship } & $-0.002^{*}$ & $-0.003^{* *}$ \\
\hline & $(0.60)$ & $(0.13)$ \\
\hline \multirow[t]{2}{*}{ Govt. effectiveness } & $0.021^{* *}$ & $0.022^{* * *}$ \\
\hline & $(0.023)$ & $(0.000)$ \\
\hline \multirow[t]{2}{*}{ Trade openness } & 0.0003 & $0.0002^{* * *}$ \\
\hline & $(0.15)$ & $(0.000)$ \\
\hline \multirow[t]{2}{*}{ Inflation } & $-0.0003^{* *}$ & $-0.0003^{* * *}$ \\
\hline & $(0.026)$ & (0.000) \\
\hline \multirow[t]{2}{*}{ Gross Fixed Capital Formation } & $0.001 * *$ & $0.001 * * *$ \\
\hline & $(0.04)$ & $(0.000)$ \\
\hline \multirow[t]{2}{*}{ Constant } & $0.3717^{* * *}$ & $0.3867^{* * *}$ \\
\hline & $(0.004)$ & (0.000) \\
\hline Chi square & 7467.26 & 582419.60 \\
\hline Sargan(p-value) & & 1.00 \\
\hline AR2 (p-value) & 0.05 & 0.35 \\
\hline Observations & 396 & 396 \\
\hline No of countries & 33 & 33 \\
\hline
\end{tabular}

*, ** and ${ }^{* *}$ represents significance level at $10 \%, 5 \%$ and $1 \%$.

Rise in level of exports shows that economy is flourishing and leading the economy towards growth. Also the imports of goods and services contribute in economic growth of developing country in sense that more imports of goods fulfill the needs of residents of country and imports of skillful human capital and machinery makes the residents efficient and competent that leads to positive changes in domestic human capital and enhancement of economic activities.

Gross fixed capital formation is positively related to economic growth, new investments on land improvements, infrastructure, plant, machinery, purchase of equipment, roads etc. can build potential in country to produce more goods and expand production network up to distant places hence employment level rises, output increases and level of economic growth rises.

\subsection{Empirical impact of ATMs/ 100,000 adults, institutions and entrepreneurship on economic growth}

In step two, we take ATMs/ 100,000 adults as proxy of financial inclusion and see its effect on growth. Proxies of political institutional variables are government effectiveness, control of corruption, rule of law and political stability. Here financial inclusion is measured with another proxy which is 
ATMs/1000oo adults.

Table 6: Control of corruption, ATMs and economic growth

\begin{tabular}{|c|c|c|}
\hline \multirow[t]{2}{*}{ VARIABLES } & \multicolumn{2}{|c|}{ SYSTEM GMM } \\
\hline & One-step & two-step \\
\hline \multirow[t]{2}{*}{ Per capita GDP(-1) } & $0.956^{* * *}$ & $0.956^{* * *}$ \\
\hline & $(0.000)$ & $(0.000)$ \\
\hline \multirow[t]{2}{*}{ ATMs/100,ooo adults } & 0.0003 & $0.0003^{* * *}$ \\
\hline & $(0.40)$ & $(0.000)$ \\
\hline \multirow[t]{2}{*}{ Entrepreneurship } & -0.002 & -0.003 \\
\hline & $(0.70)$ & $(0.31)$ \\
\hline \multirow[t]{2}{*}{ Control of corruption } & $0.006^{* * *}$ & $0.007^{* *}$ \\
\hline & $(0.017)$ & $(0.05)$ \\
\hline \multirow[t]{2}{*}{ Trade openness } & 0.0003 & $0.0002^{* * *}$ \\
\hline & $(0.17)$ & $(0.000)$ \\
\hline \multirow[t]{2}{*}{ Inflation } & $-0.0003^{* * *}$ & $-0.0003^{* * *}$ \\
\hline & $(0.01)$ & (0.000) \\
\hline \multirow[t]{2}{*}{ Gross Fixed Capital Formation } & $0.001^{* * *}$ & $0.001^{* * *}$ \\
\hline & $(0.01)$ & $(0.000)$ \\
\hline \multirow[t]{2}{*}{ Constant } & $0.36^{* * *}$ & $0.35^{* * *}$ \\
\hline & $(0.01)$ & $(0.000)$ \\
\hline Chi square & 7438.45 & 54911.77 \\
\hline Sargan(p-value) & & 1.00 \\
\hline AR2 (p-value) & 0.05 & 0.32 \\
\hline Observations & 396 & 396 \\
\hline No of countries & 33 & 33 \\
\hline
\end{tabular}

$*, * *$ and $^{* * *}$ represents significance level at $10 \%, 5 \%$ and $1 \%$.

Financial inclusion shows positive relationship with economic growth although the value of coefficient of ATMs/1000oo adults is smaller than value of coefficient of CBBs/1000oo adults but both are highly significant. The positive relationship shows that increase in number of ATMs connect more people to banking services. By more connection with banking services means that savers and investors are getting more benefits from services provided by commercial banks that increase the level of financial inclusion which in turn leads to growth of country.

Table 7: Rule of law, ATMs and economic growth

\begin{tabular}{|lcc|}
\hline VARIABLES & \multicolumn{2}{c|}{ SYSTEM GMM } \\
\hline Per capita GDP(-1) & One-step & two-step \\
\hline & $0.95^{* * *}$ & $0.957^{* * *}$ \\
\hline ATMs/100,000 adults & $(0.000)$ & $(0.000)$ \\
\hline & 0.0003 & $0.0003^{* * *}$ \\
\hline Entrepreneurship & $(0.36)$ & $(0.000)$ \\
\hline
\end{tabular}


Review of Economics and Development Studies, Vol. 6 (1) 2020,

\begin{tabular}{|lll|}
\hline & $(0.69)$ & $(0.01)$ \\
\hline Rule of law & -0.005 & $-0.008^{* * *}$ \\
\hline Trade openness & $(0.79)$ & $(0.006)$ \\
\hline Inflation & 0.0003 & $0.0002^{* * *}$ \\
\hline & $(0.17)$ & $(0.000)$ \\
\hline Gross Fixed Capital Formation & $-0.0003^{* *}$ & $-0.0003^{* * *}$ \\
\hline & $(0.021)$ & $(0.000)$ \\
\hline Constant & $(0.02)$ & $0.001^{* * *}$ \\
\hline & $0.3500^{* * *}$ & $0.3427^{* * *}$ \\
\hline Chi square & $(0.000)$ & $(0.000)$ \\
\hline Sargan(p-value) & 7404.00 & 43813.60 \\
\hline AR2 (p-value) & & 0.35 \\
\hline Observations & 0.05 & 396 \\
\hline No of countries & 396 & 33 \\
\hline
\end{tabular}

$*, * *$ and ${ }^{* *}$ represents significance level at $10 \%, 5 \%$ and $1 \%$.

Both institutions and financial inclusion are necessary for economic growth because Adetiloye (2017) in his study show that financial inclusion does not support economic growth in Nigeria and is recommended to not only deepen financial inclusion through credit delivery to private sector but also to allocate and use resources efficiently by authorities of Nigeria. Entrepreneurship has negative and insignificant relationship with economic growth. In developing countries the entrepreneurship and economic growth shows same result (Van Stel et al. 2005). There might be many reasons behind this relationship. One given by Van Stel et al. is institutional failure. Other reasons might be limited transportation facility, lack of human skills and poor management. In developing countries the resources are less and environment for productive activities is not suitable.

Table 8. Political stability, ATMs and economic growth

\begin{tabular}{|lcc|}
\hline VARIABLES & \multicolumn{2}{c|}{ SYSTEM GMM } \\
\hline Per capita GDP(-1) & One-step & two-step \\
\hline & $\left(0.963^{* * *}\right.$ & $0.964^{* * *}$ \\
\hline ATMs/100,ooo adults & 0.0003 & $(0.000)$ \\
\hline & $(0.40)$ & $0.0002^{* * *}$ \\
\hline Entrepreneurship & -0.002 & $(0.000)$ \\
\hline & $(0.77)$ & $-0.003^{*}$ \\
\hline Political stability & $-0.006^{* *}$ & $(0.10)$ \\
\hline & $(0.047)$ & $-0.006^{* * *}$ \\
\hline Trade openness & 0.0002 & $(0.007)$ \\
\hline & $(0.20)$ & $0.0002^{* * *}$ \\
\hline Inflation & $-0.0004^{* * *}$ & $(0.001)$ \\
\hline & $(0.016)$ & $-0.0003^{* * *}$ \\
\hline
\end{tabular}


Review of Economics and Development Studies, Vol. 6 (1) 2020,

\begin{tabular}{|lll|}
\hline Gross Fixed Capital Formation & $0.001^{* * *}$ & $0.001^{* * *}$ \\
\hline Constant & $(0.01)$ & $(0.000)$ \\
\hline & $0.297^{* *}$ & $0.297^{* * *}$ \\
\hline Chi square & $(0.034)$ & 162163.30 \\
\hline Sargan(p-value) & 7372.65 & 1.00 \\
\hline AR2 (p-value) & & 0.30 \\
\hline Observations & 0.06 & 396 \\
\hline No of countries & 396 & 33 \\
\hline
\end{tabular}

$*, * *$ and $^{* * *}$ represents significance level at $10 \%, 5 \%$ and $1 \%$.

Trade openness has positive relationship with economic growth. Increase in trade of country shows that exports and imports of country are more. If exports are greater than imports then trade is surplus and the economy of that country gains. If imports are greater than exports then economy loses. But for developing countries the imports of goods and services can be beneficial when human capital of resident country become skillful by working with foreign skilled labor. Hence trade of developing country play positive role in the growth of economy.

Inflation is negatively related to economic growth. Increase in prices of goods and services directly affect the demand for those goods and services. As in developing countries mostly the people living in these countries are poor. With inflation they cut off their demand for expensive goods and services hence decrease in demand for such goods and services leads to cut off in production of expensive goods and services and growth decreases. Gross fixed capital formation is positively related to economic growth that shows when investment level is high then economy grow. More investment means an economy is producing more goods and services. More employees are hired to produce these goods that generate employment. This enhances the level of income which increases in turn demand for goods and services. In this way economy expands and grows.

\section{Conclusion and Policy Recommendations}

This study examines the effect of financial inclusion, entrepreneurship and institutions on economic growth of developing countries. For financial inclusion two proxies are used such as Commercial Banks Branches/1000oo adults and Automated Teller Machine/100ooo adults. Using panel data for 33 developing countries the system GMM is used to set up the relationship between financial inclusion and economic growth.

Summary of the results is as follows. Financial inclusion has positive relationship, entrepreneurship has negative and some institutional variables has positive while some has negative relationship with economic growth. As financial inclusion is measured with two variables Commercial banks branches per lac adults and ATMs per lac adults and both variables have positive relationship with economic growth and is highly significant. Entrepreneurship shows negative but significant relationship with economic growth.

Four proxies of institutions such as rule of law, political stability, control of corruption and government effectiveness are used in step one where financial inclusion is measured with Commercial banks branches/1000oo adults. Financial inclusion has positive and significant effect on economic growth. Rule of law has negative but insignificant effect on economic growth and political stability has negative and significant effect on economic growth. Government effectiveness and control of corruption 
have significant positive relation with economic growth. Entrepreneurship has negative and significant effect on economic growth. Trade openness and Gross Fixed Capital Formation have positive and significant relationship while inflation has showed negative and significant relationship with growth.

In second step four institutional variables are used with Automated Teller Machines/10oooo adults that is another proxy of financial inclusion. financial inclusion is positively related to economic growth. The effect of CBBs/1000oo adults is stronger to ATMs/100ooo adults because the coefficient of $\mathrm{CBBs} / 100000$ is greater. Here again Entrepreneurship and inflation have showed negative relation with economic growth. Institutional variables like government effectiveness and Control of corruption are positively correlated with economic growth whereas Rule of law and political stability have negative and significant relationship with economic growth. Trade openness and Gross Fixed Capital Formation are positively related to economic growth.

\section{Limitations of Study}

Data of entrepreneurship, financial inclusion were not available for most of the developing countries that is why only 33 low income and lower middle income countries are studied.

\section{Policy Recommendations}

According to the conclusion of present study it is recommended that

- Financial inclusion is a tool applied by economies to target lower income group especially to make them able to participate in economic activities by providing them goods and services at reasonable price. If it is so, then it means lower income group of economy can play their role in economic growth. Then Government of developing countries should take effective steps to increase financial inclusion so that this factor can enhance economic growth beside other factors as well.

- There is need for reforms of institutional quality. Government should improve the institutions that perform best in economy. The tools of economic growth would be effective if the institutions work under proper supervision of Government.

\section{Scope for Future Research}

In present study, the impact of financial inclusion and entrepreneurship is examined on economic growth but researchers can study the impact of financial inclusion on inclusive growth. This study can be extended further for developed countries or by comparing the effects on low and high income countries.

\section{References}

Alter, A. and B. Yontcheva. 2015. Financial Inclusion and Development in the CEMAC. IMF Working Paper. WP/15/235.

Amidzic et al. 2014. Assessing Countries' Financial Inclusion Standing-A new Composite Index. International Monetary Fund Working Paper. WP/14/36.

Archana, H. N. 2013. Financial Inclusion- Role of Institutions. Innovative Journal of Business and Management $2: 44-48$.

Ardic, O.P., M. Heimann and N. Mylenko. 2011. Access to Financial Services and the Financial Inclusion Agenda around the World. A Cross-Country Analysis with a New Data Set. Policy Research Working Paper 5537. WPS5537.

Autio, Erkko. and Kun Fu. 2015. Economic and Political Institutions and entry into formal and informal entrepreneurship. Asia Pacific Journal of Management 32: 67-94.

Chen, Zibei. And Minchao Jin. 2017. Financial Inclusion in China: Use of Credit. J Fam Econ Iss. 
Cravo, Tulio. A., Gourly, Adrian. and Beckar, Bettina. 2012. SMEs and regional economic growth in Brazil. Small Business Economics 38: 217-230.

Demirguc-Kunt, A. and L. Klapper. 2012. Financial Inclusion in Africa: An Overview. Policy Research Working Paper 6o88. The World Bank. WPS6o88

Dixit, R. and M. Ghosh. 2013. Financial Inclusion for Inclusive Growth of India - A Study of Indian States. International Journal of Business Management \& Research (IJBMR) 3(I): 147-156.

Estrada, G., D. Park and A. Ramayandi. 2010. Financial Development and Economic Growth in Developing Asia. Asian Development Bank (ADB) Economics Working Paper Series No. 233.

Fadun, S. O. 2014. Financial Inclusion Tool for Poverty Alleviation and Income Redistribution in Developing Countries: Evidences from Nigeria. Academic Research International 5(3): 137-146.

Hariharan, G and M. Marktanner 2013. The Growth Potential from Financial Inclusion

Kim, Dai-Won., Yu, Jung-Suk. and Hassan, M. Kabir. 2018. Financial inclusion and economic growth in OIC countries. Research in International Business and Finance 43: 1-14.

King, R.G. and R. Levine. 1993. Finance and Growth: Schumpeter might be right. Quarterly Journal of Economics 108: 717-737.

Martin, Galindo., Picazo, Mendiz. and Navarro, Alfaro. 2010. Entrepreneurship, income distribution and economic growth. International Entrepreneurship Management Journal 6: 131-141.

Nissan, Edward., Martin, M.A Galindo. and Picazo, M.T Mendez. 2011. Relationship between organization, institutions, entrepreneurship and economic growth process. International Entrepreneurship Management Journal 7: 311-324.

Nystrom, Kristina. 2008. The Institutions of Economic Freedom and Entrepreneurship: Evidence from panel data. Public Choice. 136: 269-282.

Prochniak, Mariusz. and Katarzyna, Wasiak. 2017. The impact of Financial system on economic growth in context of the global crisis: empirical evidence of the EU and OECD countries. Empirica 44: 295-337.

Rajan, R. G. and L. Zingales. 1996. Financial Dependence and Growth. NBER Working Paper Series. Working Paper No.5758.

Sarma, M. 2010. Index of financial inclusion. Center for International Trade and Development. Discussion Paper No. 10-05.

Seminar on "Financial Inclusion for Entrepreneurship and Innovation" December 2015, New Dehli India.

Umer, Faiza. 2014. Impact of Trade Openness on Economic growth of Pakistan: An

ARDL approach. Journal of Business and Economic Policy. 1: 39-59.

Oji, Chijioke Kennedy. 2015. Promoting Financial Inclusion for Inclusive Growth in

Africa. Occasional Paper 210. Economic Diplomacy Programme. South

African Institute of International Affairs. African Perspectives. Global Insights

Onaolapo, A.R. 2015. Effects of Financial Inclusion on the Economic Growth of

Nigeria (1982-2012). International Journal of Business and Management

Review. 3(8): 11-28.

Kelkar, Vijay. 2010. Financial Inclusion for Inclusive Growth. ASCI Journal of

Management. 39(1): 55-68.

Hunter, Shawn. 2015. Developing Lending infrastructure for Financial Inclusion.

Asia-Pacific forum on Financial Inclusion.

Islam, Ezazul and Mamun, Salim Al. 2011. Financial Inclusion: The Role of

Bangladesh Bank. Working Paper series: WP1101.

Dhillan, Lakshwinder Kaur and Mittal, Nipun. 2016. Inclusive Growth and Financial

Inclusion ( Issues and Challenges). American International Journal of 
Research in Humanities, Arts and Social Sciences. 14(2): 145-150.

Adetiloye, Kehinde A. Okoye Lawrence Uchenna. Erin, Olayinka. and Modebe, Nwanneka. 2017. Financial Inclusion as a Strategy for Enhanced Economic Growth and Development. Journal of Internet banking and Commerce. 22(S8). Babajida, Abiola A. Adegboye, Folasade B. and Omankhanlen, Alexander E. 2015. Financial Inclusion and Economic Growth in Nigeria. International Journal of Economics and Financial Issues. 5(3): 629-637.

Christopoulos, Demitris K. and Tsionas, Efthymios G. 2004. Financial Development and Economic Growth:Evidence from panel unit root and cointegration tests. Journal of Development Economics. 73: 55-74. Commander, Simon. and Nikoloski, Zlatko. 2010. Institutions and Economic Performance: What can be explained? Working paper no 121. Unbreen, Qayyum. and Nawaz, Muhammad. 2014. Remittances and Economic Growth: The role of Financial Development. Pakistan Institute of Development Economics Working Paper 2014:100.

Romer, P. 1986. Increasing Returns and Long run Growth. Journal of Political Economy. 94(5): 1002-1037.

Solow, R. M. 1956. A Contribution to the Theory of Economic Growth. Quarterly Journal of Economics. 70(1): 65-94.

Blundell, R., \& Bond, S. 1998. Initial Conditions and Moment Restrictions in Dynamic Panel Data Models. Journal of Econometrics. 87(1): 111-143.

Arellano, M. and Bond, S. 1991. Some Tests of Specification for Panel Data: Monte Carlo Evidence and an Application to Employment Equations. Review of Economic Studies. 58(2): 277-297.

Lucas, R. 1988. On the Mechanics of Economic Development. Journal of Monetory Economics. 22: 3-42.

Beck, Thorsten. Demirguc-Kunt, Asli., and Levine, Ross. 2007. Finance, Inequality and the Poor. Journal of Economic Growth. 12(1): 27-49.

World Bank. 2008. Finance for all? Policies and Pitfalls in Expanding Access. The Washington, DC: World Bank.

Arellano, M., and O. Bover 1995. Another Look at the Instrumental Variable Estimation of Error-Components Models. Journal of Econometrics. 68:29-51. Anderson, T.W., and C. Hsiao 1982. Formulation and Estimation of Dynamic Models Using Panel Data. Journal of Econometrics. 18: 47-82.

Romer, David. Mankiw, N. Gregory., and Weil, David.N. 1992. A Contribution to the Empirics of Economic Growth. Quarterly Journal of Economics. 407-437. Bjornskov, Christian., and Foss, Nicolai J. 2008. Economic Freedom and Entrepreneurial activity: Some cross-country evidence. Journal of Public Choice. 134: 307-328.

Giri, A.K., and Sehrawat, Madhu. 2017. The Impact of Financial Development, Economic Growth, income inequality on poverty: evidence from India. Journal of Empirical Economics. 
Table 1: Descriptive Statistics

\begin{tabular}{|c|c|c|c|c|c|}
\hline Variables & Mean & Std. Dev. & Min & Max & \\
\hline Per capita GDP & 429 & 7.29 & 0.69 & 5.68 & 8.36 \\
\hline Consumer price index & 429 & 101.43 & 27.46 & 40.72 & 210.53 \\
\hline Trade openness & 429 & 75.73 & 31.17 & 0.17 & $155 \cdot 76$ \\
\hline Gross fixed capital formation & 429 & 23.99 & 8.68 & 2.05 & 68.02 \\
\hline New Business registered & 429 & 8.25 & 1.86 & 2.30 & 11.54 \\
\hline Commercial Banks Branches & 429 & 9.89 & 11.10 & 0.37 & 71.61 \\
\hline \multicolumn{6}{|l|}{ per 100,000 adults } \\
\hline ATMs per 100,000 adults & 429 & $14 \cdot 31$ & 17.68 & -0.03 & 103.87 \\
\hline Credit to private sector & 429 & 29.94 & 18.08 & 1.07 & 80.84 \\
\hline Rule of Law & 429 & -0.58 & 0.53 & -1.90 & 0.56 \\
\hline Control of corruption & 429 & -0.57 & 0.56 & -1.67 & 1.28 \\
\hline Political stability and & 429 & -0.64 & 0.93 & -2.81 & 1.38 \\
\hline \multicolumn{6}{|l|}{ Absence of violence } \\
\hline Government effectiveness & 429 & -0.54 & 0.51 & -1.75 & 0.6 \\
\hline
\end{tabular}

\section{APPENDIX B}

Table 2. Description and source of variables.

\begin{tabular}{|c|c|c|}
\hline Variable & Description & ource \\
\hline \multirow[t]{2}{*}{ Per capita growth } & value of goods and services & WDI \\
\hline & \multicolumn{2}{|l|}{ at current price in a year } \\
\hline Consumer price & An index of prices used to measure & WDI \\
\hline index & \multicolumn{2}{|l|}{ inflation of economy } \\
\hline Trade percentage of & It is difference of imports and exports & WDI \\
\hline GDP & \multicolumn{2}{|l|}{ used to measure trade openness } \\
\hline Commercial bank & \multirow{2}{*}{\multicolumn{2}{|c|}{$\begin{array}{l}\text { It is measured as no of commercial bank } \quad \text { WDI } \\
\text { branches per } 100,000 \text { adults }\end{array}$}} \\
\hline Branches / 100000 adults & & \\
\hline \multirow[t]{2}{*}{ ATMs/ 100000 adults } & It is measured as no of ATMs & WDI \\
\hline & \multicolumn{2}{|l|}{ per 100,000 adults } \\
\hline \multirow{2}{*}{\multicolumn{3}{|c|}{$\begin{array}{c}\text { Gross fixed capital formation It is variable used to measure } \\
\text { investment }\end{array}$}} \\
\hline & & \\
\hline New business registered & It is variable used to measure & WDI \\
\hline
\end{tabular}




\begin{tabular}{|lll|}
\hline (numbers) & entrepreneurship & \\
\hline Control of corruption & it is variable whose value range & WGI \\
\hline & range between -2.5 to 2.5. & \\
\hline Rule of law & it is variable whose value range & WGI \\
\hline & range between -2.5 to 2.5. & WGI \\
\hline Political stability & it is variable whose value range & \\
\hline & range between -2.5 to $2.5 \cdot$ & WGI \\
\hline & & \\
\hline Government effectiveness & it is variable whose value range & \\
\hline & range between -2.5 to 2.5. & \\
\hline
\end{tabular}

\section{Appendix C}

Table 3. List of countries

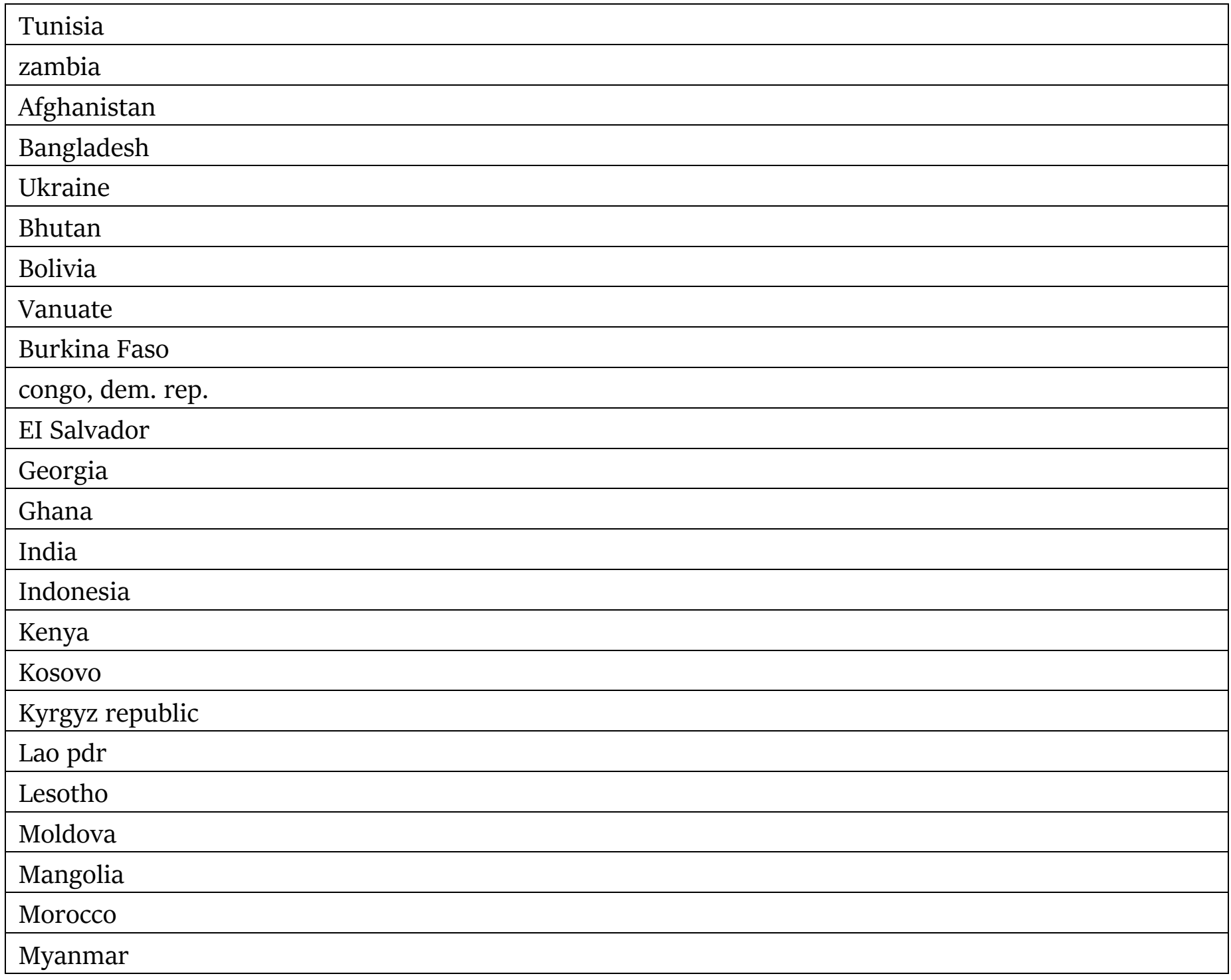


Nepal

Nigeria

Pakistan

Phillpines

Rawanda

Senegal

Srilanka

Timor-leste

Togo 